\title{
Morphological features of coilocytary atypism of squamous papillomas of dogs
}

\author{
Natalia Kudacheva* \\ Samara State Agrarian University, Kinel 446442, Russia
}

\begin{abstract}
Coilocytic atypism of tumors of epithelial origin is considered as a marker of HPV infection, regardless of the type of neoplasm, which is a clinical manifestation of papillomatosis. Many neoplasms in dogs are diagnosed depending on the identification of specific cellular and tissue atypism, which underlies the histological diagnosis. According to the recent studies, the following types of neoplasm can be distinguished depending on the taxonomic affiliation of HPV: papillomas of various localization, cancerous epidermodysplasia verruciformis, pigment affects (including plaque), inverted and squamous papillomas, squamous cell carcinomas. Histological studies are an affordable diagnostic method that allows studying the morphological features of coylocytary atypism of squamous papillomas of dogs. Squamous cell papillomas in dogs have a number of morphological and cytological features, due to the predominance of the keratinization process. In this case, the process of differentiation of epithelial cells is consistent and all layers typical of the skin of dogs are distinguished. The corneal layer prevails over all the described layers, the activity of the cells of the basal layer is noted. Coilocytes are localized in a spinous and granular layer, but depending on their location, they have distinctive morphological and quantitative characteristics. Despite the polymorphism of the manifestation of coylocytary atypism in animals within the limits of specific affects, as well as depending on the type of neoplasm, there are no common morphological criteria for evaluating coylocytosis depending on oncogenesis. It was noted that the morphological and quantitative characteristics of coilocytes depend on their location, while they have a morphology described by many researchers, including in various animal species.
\end{abstract}

\section{Introduction}

The diagnosis of animal papillomatosis is mainly focused on the identification of certain histological informative criteria characteristic of neoplasms in accordance with the morphological classification of tumors [1]. Histological analysis is a differential diagnostic method that allows identifying epithelial neoplasms with oncogenic potential [2, 3]. Exophytic papillomas, including squamous papillomas, endophytic inverted papillomas, pigmented plaques and invasive squamous cell carcinomas of dogs are associated with HPV, which goes beyond the causal relationship of the virus only with oral papillomatosis $[4,5]$.

A morphological criterion for epithelial affects in papillomatosis is considered to be coilocyte, a cell of the intermediate or superficial layer of a stratified squamous epithelium with discariosis and a perinuclear "enlightenment" zone [6]. The term coilocyte is derived from the Greek word koillos, which means "cavity" [7]. Histological studies reveal other specific morphological features, in particular different degrees of hyperkeratosis or parakeratosis, proliferation of squamous epithelium, in the form of multiple finger-shaped formations [8, 9].

A typical feature of parenchymal epidermis in papillomatosis is the presence of altered spinous layer of epithelial cells with signs of coilocytic activity, pronounced vacuolization, the formation of perinuclear zones of enlightenment and destruction of the cell structure [10].

Recent scientific studies confirm the spread of papillomatosis among animals in which it was not described previously. The authors of the publications noted that coylocytary atypism accompanies oncogenesis, regardless of the type of animal, in particular, when studying lesions of the wild American beaver, camels, specific coylocytosis was also detected $[11,12]$.

Thus, the histological criteria characteristic of papillomatous lesions is acanthosis, coilocytosis, hyperkeratosis, parakeratosis, but the identification of possible morphological features of coilocytes in various neoplasms is limited.

\section{Materials and methods}

\subsection{Research object}

The research object was presented by the dogs with clinical signs of papillomatous affects, which were admitted to the conditions of veterinary clinics for

Corresponding author: NAlmakaeva@yandex.ru 
diagnosis and treatment. After the epizootological analysis and clinical diagnosis, the material was selected for subsequent histological examination of neoplasms. Neoplasms were removed surgically, after preliminary anesthesia at the site of surgical removal of papillomas with $2 \%$ lidocaine solution.

\subsection{Histological method of diagnosis}

After preliminary fixation of the obtained material with a $10 \%$ formalin solution, hematoxylin-eosin staining was carried out, followed by morphohistological examination, in order to study tissue topology and cell structure. Histological preparations were performed on a freezing microtome MZP-01 "Technom", with further staining with hematoxylin and eosin.

The study of histological sections included the method of light-optical microscopy using a LUMAM I1 microscope. Papillomas were subsequently classified into papillomas and squamous papillomas. The diagnosis was made on the basis of the presence of typical cytopathic symptoms, such as epidermal proliferation, coilocytosis, hyperkeratosis, parakeratosis [13]. Histological examination of squamous papillomas took into account signs of cell atypism, structural features of the epithelial layers and their stratification. Such indicators as the shape and size of cells, the area of coilocytes and other epithelial cells, and the nuclearcytoplasmic ratio were studied.

\section{Results}

The clinical diagnosis of papillomatosis in dogs is not particularly difficult. Neoplasms are characterized by exophytic growth, different localization; the surface imitates the structure of the skin, which allows them to be referred to tumors of epithelial origin during visual examination (Fig. 1).

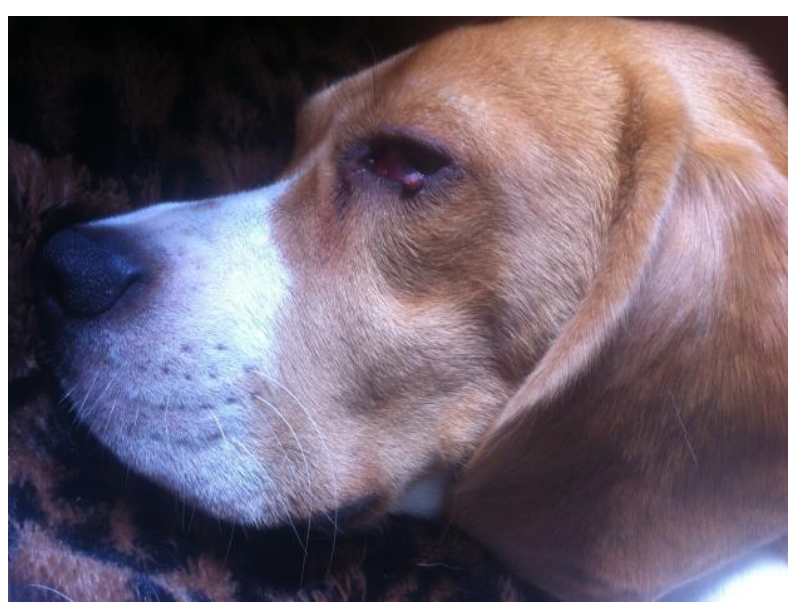

Fig. 1. Clinical signs of dog lower eyelid papillomatosis

Microscopically, squamous papillomas of dogs are represented by hyperplastic epithelium, with a stromal component consisting of vascularized fibrous tissue in the form of multiple finger-shaped formations.
During the study of the epithelial layers, various morphological types of cells are distinguished. It was noted that the tumor parenchyma imitates the structure of the epidermis of the skin and is represented by all layers observed normally in dogs (Fig. 2.).

Regardless of the layer, geometric variation in the shape of the cells is noted, apparently, to preserve the architectonics of the cell layers, ensuring its formation and to change the spatial organization of cells. The basic membrane is preserved, signs of acanthosis are noted. Depending on the epithelial layer, various morphological types of cells are distinguished.

The basic layer averages $40.2 \pm 0.74 \mathrm{mcm}$ and is represented by basic cells located in several rows, binuclear cells are observed. The nuclei of the basic cells are oval-shaped; the randomness of the arrangement of cells due to mitotic activity is noted.

In the spinous layer, cellular polymorphism is noted, represented by keratinocytes, diskeratocytes and koilocytes. The thickness of the spinous layer is $35.4 \pm$ $1.52 \mathrm{mcm}$, which is less than the thickness of the basic layer. Diskeratocytes have an average area of $1302.22 \pm$ $12.3 \mathrm{mcm}^{2}$, the nuclei are hyperchromic, and the cytoplasm is eosinophilic.

The increase in signs of dysplasia in the spinous and granular layers was accompanied by the formation of coilocytes and their advancement in the process of differentiation of cells of the epithelial layers to the surface of squamous papillomas.

Table 1. Morphometric cell indicators of squamous papilloma cells of dogs

\begin{tabular}{|c|c|c|c|}
\hline $\begin{array}{l}\text { Epithelial cell } \\
\text { (taking into } \\
\text { account } \\
\text { localization) }\end{array}$ & $\begin{array}{l}\text { Cell Area, } \\
\mathrm{mcm}^{2}\end{array}$ & $\begin{array}{c}\text { Cell } \\
\text { nucleus } \\
\text { area, } \\
\mathrm{mcm}^{2}\end{array}$ & $\begin{array}{l}\text { Nuclear } \\
\text { cytoplasmic } \\
\text { ratio }\end{array}$ \\
\hline $\begin{array}{c}\text { Basic cell } \\
\text { (basic layer) }\end{array}$ & $\begin{array}{l}488.58 \\
\pm 6.84\end{array}$ & $\begin{array}{l}108.57 \\
\pm 0.24\end{array}$ & $0.29 \pm 0.04$ \\
\hline $\begin{array}{l}\text { Keratinocyte } \\
\text { (spinous layer) }\end{array}$ & $\begin{array}{l}554.93 \\
\pm 5.02\end{array}$ & $\begin{array}{l}162.86 \\
\pm 0.36\end{array}$ & $0.42 \pm 0.02$ \\
\hline $\begin{array}{l}\text { Keratinocyte } \\
\text { (granular } \\
\text { layer) }\end{array}$ & $\begin{array}{l}850.495 \\
\pm 10.65\end{array}$ & $\begin{array}{l}144.77 \\
\pm 0.74\end{array}$ & $0.21 \pm 0.01$ \\
\hline $\begin{array}{c}\text { Coilocyte } \\
\text { (spinous layer) }\end{array}$ & $\begin{array}{l}2026.71 \\
\pm 12.07\end{array}$ & $\begin{array}{l}325,22 \\
\pm 0.84\end{array}$ & $0.12 \pm 0.01$ \\
\hline $\begin{array}{c}\text { Coilocyte } \\
\text { (granular layer) }\end{array}$ & $\begin{array}{l}4632.47 \\
\pm 13.16\end{array}$ & $\begin{array}{c}1542.17 \\
\pm 9.32\end{array}$ & $0.5 \pm 0.06$ \\
\hline
\end{tabular}

The granular layer is $39.1 \pm 2.16 \mathrm{mcm}$, the cell structure is polymorphic and is mainly represented by keratinocytes, diskeratocytes and coilocytes. Coilocytes reach their maximum sizes and in some cases are represented by binuclear cells. The perinuclear space morphologically looks like a cavity among epithelial cells.

Thickening of corneal layer and the presence of signs of hyperkeratosis and parakeratosis up to $57.78 \pm 1.02$ $\mathrm{mcm}$ are noted, moreover, they accompany all the 
studied samples, but are non-specific histological signs. Other cytomorphometric indicators are indicated in Table 1.

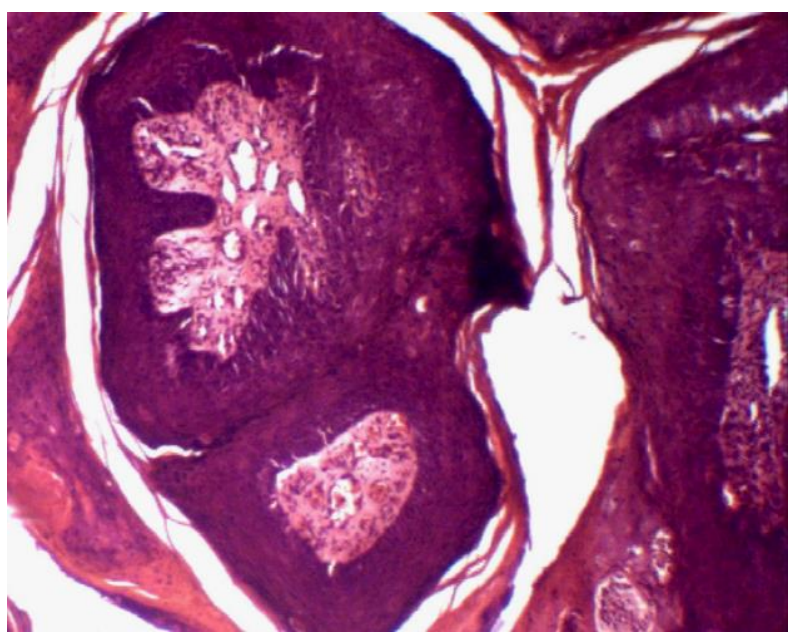

Fig. 2. Squamous cell papilloma of dogs. Hematoxylin and eosin staining, uv. about $\mathrm{x} 10$, about. x10

Coilocytes are polymorphic depending on localization relative to the epithelial layer of the parenchyma. Spinous layer coylocytes with signs of vacuolization of the nucleus abd inclusion bodies are noted. As the coilocyte advances into the granular layer during the process of differentiation of the epithelium, the increase and polymorphism of the nucleus are observed, around which there is a clarification of the cytoplasm and intranuclear inclusion bodies (Fig. 3).

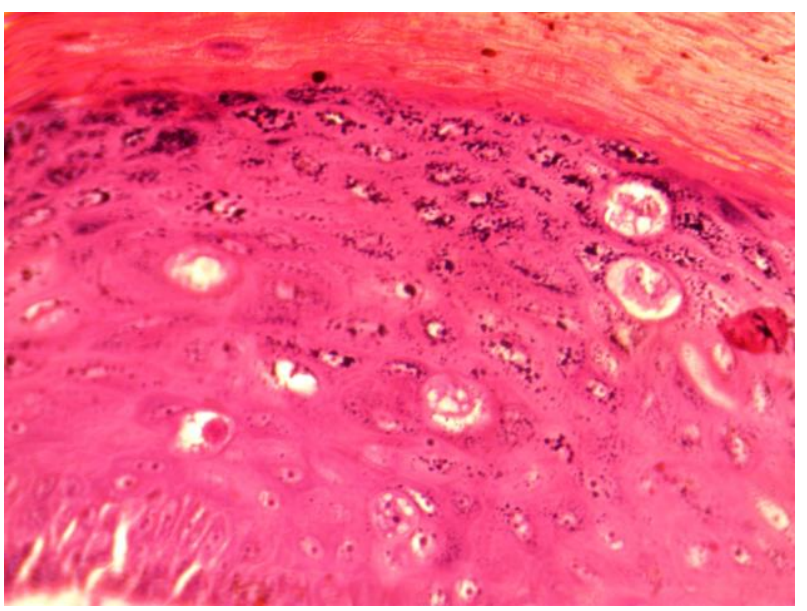

Fig. 3. Coilocytic atypism of spinous and granular layers. Hematoxylin and eosin staining, uv. about x10, about x40.

According to the above mentioned aspects, it is necessary to note that the hyperplastic epithelium of squamous papillomas in a quantitative ratio is mainly represented by the basic and corneal layers, the total thickness of which is about $100 \mathrm{mcm}$, while the spinous and granular layers are no more than $75 \mathrm{mcm}$. The formation of squamous papillomas in dogs is a process focused on providing new epithelial layers due to basal cells, followed by keratinization. The spinous and granular layers are the localization site of coilocytes with their characteristic structure. With the differentiation of the epithelium, the area of coilocytes, including the nuclei of cells, increases, which indicates the sequential appearance of signs of vacuolization, then zones of enlightenment, with the formation of perinuclear space and nuclear deformation.

\section{Discussion}

In accordance with the latest scientific data, HPVs are associated with various affects of skin and mucous membranes, which slightly changes the idea of the causes of neoplasms. It is noted that due to their tissue specificity, they can be grouped depending on localization, i.e. damaging skin cells and mucosal cells [14-16].

Papillomas are proliferative non cancerous tumors with complex pathogenesis [17], characterized by numerous thin fibrovascular outgrowths covered with hyperplastic epithelium. Exophytic growth of squamous papillomas of dogs is accompanied by the formation of finger-shaped protrusions above the skin surface. Epithelial cells of neoplasms retain their usual polarity and maturation sequence [18].

Coilocytosis in dogs is described by histological examination of such oncological processes as papilloma, including squamous and inverted, pigmented plaque, squamous cell carcinoma. Coilocytic atypism in these cases is described with the indication of the typical morphology of coilocytes and their preferential localization, associating their presence with HPV infection.

The structure of the neoplasm parenchyma is characterized by a different degree of hyperkeratosis or parakeratosis, as well as proliferation of squamous epithelium. In all cases, papillomas are described as tumors in the form of "cauliflower". Most coilocytes within the spinous layer show the formation of a clear perinuclear halo, some cells have a pyknotic nucleus. Some authors have revealed discrete spherical degeneration or fusion of neighboring degenerative cells, with the formation of microspaces $[19,20]$.

Coilocytosis as a specific manifestation of papillomatosis is not limited to species priority, it is noted in neoplasms of heterologous animal species, and coylocytary atypism is descriptive, in particular, indicating its presence.

The formation of coilocytes is a part of the pathogenesis indicating the dynamism of the oncogenic process. Coilocytic atypism is a consequence of severe epithelial dysplasia and is described as the cytopathic effect of epithelial cells in HPV infection. Many studies showed similar histological features. The identification of coylocytary atypism is necessary to confirm the clinical diagnosis of papillomatosis and in some cases is the only possible way.

During the papillomatosis, coilocytosis is observed only in the upper, well-differentiated layers of stratified squamous epithelium, and it is in these layers (and especially in coilocytes) that the viral capsid proteins are expressed and assembled into infectious virions [21]. 
Thus, the formation of coilocytes is associated with the biological characteristics of the virus at the terminal stages of the reproductive cycle, and the final stage of the life cycle of HPV is the assembly and packaging of viral particles in its nucleus before cell death [22], and the perinuclear zone of "enlightenment" is formed as a result of necrosis [23].

Despite the fact that the coilocyte is a specific marker cell with a clear localization in spinous and granular layers, it is very difficult to identify clear morphological and quantitative characteristics. The obtained data corresponds to the works of many authors describing coylocytary atypism in various affects of heterologous animal species.

\section{Conclusion}

Thus, coilocytosis is noted in the upper part of the epidermis which forms the papillary parenchyma. Coilocytes are located in the form of focal clusters or diffusely; the shape is rounded; they have polymorphism. Polymorphism is determined by the location of cells relative to the cut surface of the papilloma, which suggests the "maturation" of the altered cells. Closer to the horny layer of the epidermis, coilocytes increase in size, the cells acquire a more flattened or ovoid shape; the nucleus is displaced to the cytoplasmic membrane and is in a state of pycnosis. A feature of the epidermis of squamous cell papillomas is the presence of altered epithelial cells at the terminal stage of coilocyte activity, with pronounced vacuolization, the formation of perinuclear zones of clarification and the destruction of the cellular structure. It should be noted that coilocytosis is a dynamic process that occurs in a prickle-cell layer of the epidermis. As the neoplasm grows, the cells with signs of coilocytary atypism move to the periphery of the papilloma, changing its morphological structure.

\section{References}

1. N. Kudacheva, Coilocytary atypism as cytomorphological criterion of papyllomatosis Veterinary science and feeding 4, 38-39 (2015) (In Russ.)

2. V. Monteiro, M. Coelho, A. Carneiro, R. Silva, M. Teixeira, A. Wan-derley, E. Wanderley, E. Franco, Descrição clínica e histopatológica da papilomatose cutânea bovina (BPV). Ciênc. Anim. Bras. 10, 550560 (2008)

3. R. Araldi, T. Melo, A. Neves, D. Spadacci-Morena, R. Magnelli, D. Módulo, P. De-Sá-Júnio, J. Mazzuchelli-de-Souza, R. Car-valho, W. Beçak, et al., Hyperproliferative action of bovine papillomavirus (BPV): Genetics and histopathological aspects Genet. Mol. Res. 14, 12942-12954 (2015)

4. N. Zaugg, G. Nespeca, B. Hauser, M. Ackermann, C. Favrot, Detection of novel papillomaviruses in canine mucosal, cutaneous and in situ squamous cell carcinomas Vet. Dermatol. 16, 290-298 (2005)

5. J. Munday, K. O'Connor, B. Smits, Development of multiple pigmented viral plaques and squamous cell carcinomas in a dog infected by a novel papillomavirus Vet. Dermatol. 22, 104-110 (2011)

6. H-K. Wang, A. Duffy, T. Broker, L. Chow, Robust production and passaging of infectious HPV in sguamous epithelium of primary human keratinocytes Genes. and Develop. 23, 181-194 (2009).

7. C. Ferraro, M. Canedo, S. Oliveira, M. Carvalho, E. Dias, Infecção oral pelo HPV e lesões epiteliais proliferativas associadas. J Bras. Patol. Médica e Lab. 47, 451-459 (2011)

8. C. Tozato, M. Lunardi, A. Alfieri, R. Otonel, G. Di Santis, B. K de Alcântara, S. Headley, A. Alfieri, Teat papillomatosis associated with bovine papillomavirus types $6,7,9$, and 10 in dairy cattle from Brazil Brazilian j. of microbiology 44, 905-909 (Brazilian Society for Microbiology, 2013)

9. V. Monteiro, M. Coelho, A. Carneiro, R. Silva, M. Teixeira, A. Wan-derley, E. Wanderley, E. Franco, Descrição clínica e histopatológica da papilomatose cutânea bovina (BPV). Ciênc. Anim. Bras. 10, 550560 (2008)

10. N. Kudacheva, Peculiarities of tissue topology and cell structure of the papillomas J. Morphology 3(153), 155-155a (2018) (In Russ.)

11. A. Rogovskyy, T. Baszler, D. Bradway, D. Bruning, C. Davitt, J. Evermann, R. Burk, Z. et al., A novel papillomavirus isolated from proliferative skin lesions of a wild American beaver (Castor canadensis) J. of Veterinary Diagnostic Investigation 24, 750-754 (2012)

12. A. Oryan, M. Hashemnia, A. Mohammadalipour et al., Gross and histopathological characteristics of fibropapilloma in camels (Camelus dromedarius) J. of camel practice and research 18, 65-68 (2011)

13. H. Cubie, Diseases associated with human papillomavirus infection Virology 445, 21-34 (2013)

14. A. Rector, M. Van Ranst, Animal papillomaviruses Virology 445, 213-223 (2013)

15. C. Lange, K. Tobler, A. Lehner, E. Vetsch, C. Favrot, A case of a canine pigmented plaque associated with the presence of a Chipapillomavirus Vet. Dermatol. 23, 76-80 (2012)

16. J. Munday, M. Dunowska, S. Hills, Genomic characterisation of canine papillomavirus type 17, a possible rare cause of canine oral squamous cell carcinoma Vet. Microbiol. 135-140 (2016)

17. M. Börkü, O. Atalay, M. Kibar, Y. Cam, A. Atasever, Ivermectin is an effective treatment for bovine cutaneous papillomatosis Res. Vet. Sci. 83, 360-363 (2007)

18. K. Campbell, J. P. Sundberg, M. H. Goldschmidt, C. Knupp, M. E. Reichmann, Cutaneous Inverted 
Papillomas in Dogs Veterinary pathology 25, 67-71 (1988)

19. J. Munday, M. Kiupel, Papillomavirus-associated cutaneous neoplasia in mammals Veterinary pathology 47, 254-64 (2010)

20. N. Egawa, T. Nakahara, S. Ohno, M. NarisawaSaito, T. Yugawa, M. Fujita, K. Yamato, Y. Natori, T. Kiyono, The Ei protein of human papillomavirus type 16 is dispensable for maintenance replication of the viral genome J. Virol. 86, 3276-3283 (2012)

21. E. Krawczyk, F. A. Suprynowicz, X. Liu et al., Koilocytosis: a cooperative interaction between the human papillomavirus E5 and E6 oncoproteins Am. J. Pathol. 173(3), 682-688 (2008)

22. P. Howley, D. Lowy, D. Knipe, P. Howley, Papillomaviruses In Fields Virology 2299-2354 (Lippincott Williams \& Wikins, Philadelphia, (2007)

23. H-K. Wang, A. Dufy, T. Broker, L. Chow, Robust production and passaging of infectious HPV in sguamous epithelium of primary human keratinocytes Genes and Develop. 23, 181-194 (2009) 